\title{
The Evolving Scope of Rural India
}

\author{
Anjan Chakravarty \\ Department of Management (Commerce), S St. Xavier's College-Autonomous, India \\ Department of Business Management, University of Calcutta, India
}

Copyright (C) 2015 by authors, all rights reserved. Authors agree that this article remains permanently open access under the terms of the Creative Commons Attribution License 4.0 International License

\begin{abstract}
The scope of rural marketing in India is undergoing an evolutionary change. When we look at the human dimensions of economic growth and development our attention is immediately drawn towards India's rural areas. Nearly three fourths of its people live there and about a third of its Gross Domestic Product (GDP) is rural in origin. In this scenario, the paper tries to assess the reasons thereof for this fruition in the scope of rural marketing, which is just not a theoretical presentation but also a practical prescription for conglomerates which would venture into this developing arena for a profitable return.
\end{abstract}

Keywords Rural Population, Rural Consumer, Rural Marketing

\section{Prelude}

Today in the era of Globalization, the Indian market is undergoing a tremendous revolution. It is now become a market of aggressive consumerism, with the increase in the purchasing power of the people. From 1995-2000, India's Gross Domestic Product (GDP) struck a compound growth rate of 5.8 percent which increased to 6.8 per cent in 2000-2005. As India's growth rate has multiplied so too the purchasing power of its citizens. Projections of Oxford Economics an 8.0 percent annual GDP growth rate between 2009 - 2018, stabilizing to 7.0 percent between 2018 and 2030.

The Indian market is classified principally into the Urban and the Rural sectors. According to the Census of 2001, any habitation with a population density of less than 400 per square kilometer, where at least 75 percent of the male working population is engaged in agriculture and where there is no municipality board could be termed as a rural market. In other words the rural market is entirely based on its villages.

Rural India accounts for almost 70 per cent of the population as the recent Census 2011 indicates that of the 1.21 billion populations, 833 million live in rural India.

The clan has been exposed to new communication technologies and a plethora of services which has strengthened its aspirations to become an urbanised society. According to a recent Technopak report, rural Indian economy is highly supported by increasing disposable income, Government initiatives and schemes and favourable demographics. As a result, the rural segment of the Indian economy is growing at a pace of 8-10 per cent per annum and is anticipated to add new consumption of US\$ 90 billon-100 billion over 2012-2017 to the current base of US\$ 240 billion-250 billion.

Moreover, the growth of rural India is largely attributed by increasing awareness about need of education. According to the ASER (2012) report, private school enrolment in rural India has enhanced by 5.5 per cent points over past six years. The literacy rate has also gone up by 68.91 per cent in rural India.

Certain amazing facts about rural India could be noted:

- 200 million rural mobile subscribers, more tha the total number of subscribers in Brazil

- 14 million DTH connections in rural areas, out of a total 20 million

- 87 million Kisan credit cards issued, which exceeds the total number of the cards in urban India

- Rural India is growing faster than the Urban India. In case of durables it is growing at the rate of 25 per cent vs.the urban gowth rate of 10 per cent in 2009. FMCGs are growing at the rate of 18 per cent vs. 12 per cent growth in 2009

- There are 42,000 rural supermarkets (haats) in India , which exceed the total number of retail chain stores in USA $(35,000)$

\section{Scope of Rural Marketing}

The scope of rural marketing entails the opportunity that exists in Indian market which could be taken advantage of by various business organizations to delve and grow in trade and commerce.

Indian and Transnational conglomerates are targeting the Indian rural market, with utmost seriousness to market their products. Conglomerates like Coca Cola, Pepsico, LG, 
Samsung, Unilever, ITC are penetrating the Indian rural market with a vengeance.

\section{Objective of the Study}

The objective is to assess the opportunity that subsists in rural marketing by analyzing the following points:

- The advantage Rural Marketing obtains from an increasing rural population

- How rural marketing could exploit the growing rural prosperity in India

- The rising consumption in rural India and its effect on the widening of the scope of rural marketing

- The change in the consumption pattern and its salutary outcome on Rural Marketing

- The reasons as to why the rural market is growing at a higher rate than the urban market

- How the urban market is reaching a saturation state

- Who are the Decision Making Units in rural India and what are their involvements in the basket of choices

Let us now examine the scope of rural marketing considering its parameters individually:

\subsection{Population}

In accordance to the Census of India, 2011, report, a rural area is considered as:

"All areas which are not categorized as Urban area are considered as Rural Area"

According to census of 2001, the number of Rural Units (or villages) in India were $6,38,588$. This increased to $6,40,867$, i.e an increase in 2,279 villages over a decade.

The population by Rural - Urban residence is given in the Table 1 below :

Table 1. Population by Rural Urban Residence -India - 2011 (Nos.)

\begin{tabular}{|c|c|}
\hline Total & $1,210,193,422$ \\
\hline Rural & $833,087,422$ \\
\hline Urban & $377,105,760$ \\
\hline
\end{tabular}

Therefore, the rural - urban distribution of population (in \%) is

$\begin{array}{ll}\text { - Total : } & 100.0 \% \\ \text { - } & \text { Rural : } \\ \text { - Urban : } & 31.16 \% \\ \end{array}$

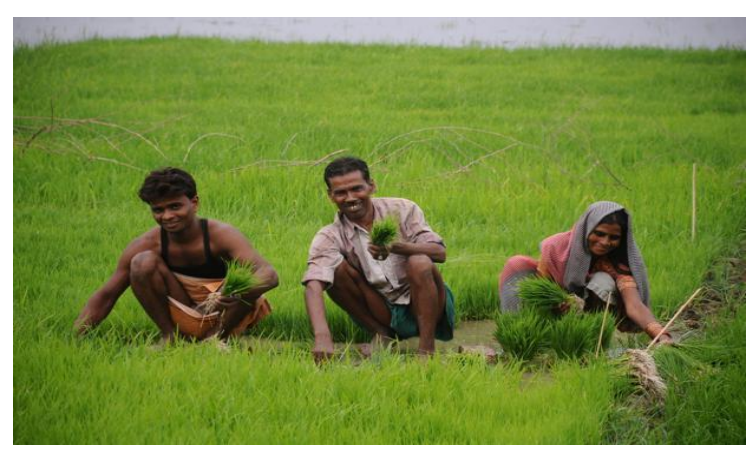

Figure 1. Rural India

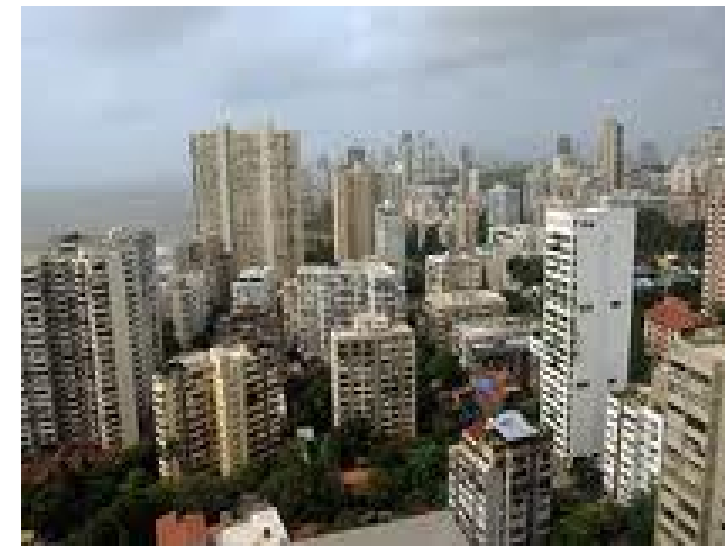

Figure 2. Urban India

Hence, we could decipher, from Table 2, that out of the total of 1210.2 million population in India, the size of Rural population is 833.1 million (or $68.84 \%$ of the total population). The Urban population is 377.1 million (or $31.16 \%)$.

Table 2. Population (in Million)

\begin{tabular}{|c|c|c|}
\hline & $\mathbf{2 0 0 1}$ & $\mathbf{2 0 1 1}$ \\
\hline India & 1029 & 1210 \\
\hline Rural & 743 & 833 \\
\hline Urban & 286 & 377 \\
\hline
\end{tabular}

(Source: Census 2011 - Provisional Population Totals - India)

During 2001 - 2011 the population of the country increased by 181 million. Out of this the Increase in Rural areas is 90million and the increase in Urban areas is 91.0 million. Four states, namely, Meghalaya (27\%) and Bihar (24\%) witnessed largest growth in rural population among States in 2001-11.

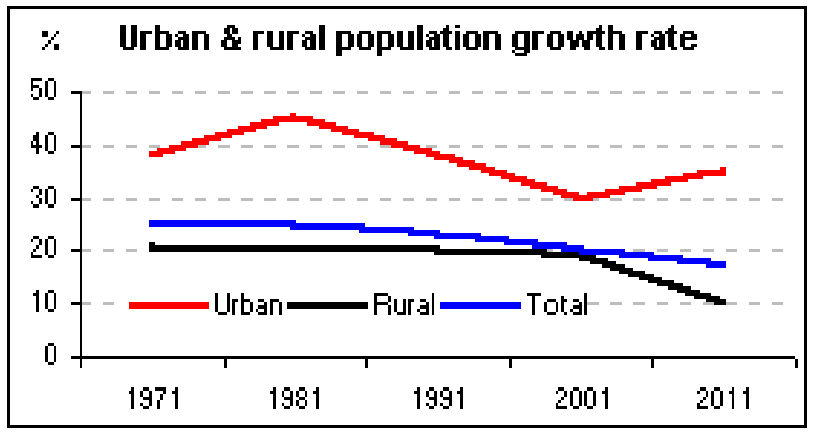

Figure 3. The Urban \& rural population growth rate

It is quite interesting to note, from Figure 3, that the rural population growth rate has diminished between 2001 and 2011. Four States recorded decline in Rural Population during 2001-11. These are Kerala (by 26\%), Goa (19\%), Nagaland (15\%) \& Sikkim (5\%).

The reason for the decreasing in growth rate is owing to the fact that the literacy in rural areas especially among women has had a very positive effect. As a result the women fertility rate has also declined. Moreover, people have shifted 
to the urban areas in search of employment and better living. But in absolute quantum the total rural population size makes the rural India a very lucrative destination for the marketers.

\section{Rural - Urban Population Divide}

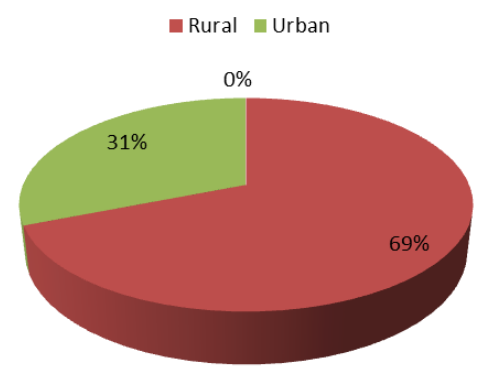

Figure 4. The Rural - Urban Population Divide

If we go by statistics,(refer Figure 4), roughly around $70 \%$ of the Indian population lives in the rural areas. That is almost $12 \%$ of the world population. To expand the market by tapping the countryside, more and more MNCs and domestic companies are foraying into India's rural market.

Consumption in rural India is growing faster than in urban India. Given the large size of India's rural population, the value of goods and services consumed has always been greater in rural India, but urban India had narrowed the differential during most of the last decade by growing at a faster pace. Between 2009-10 and 2011-12, additional spending by rural India was Rs.3,750 billion, significantly higher than Rs.2,994 billion by urbanites.

Remarkable multiplier effect of the rural population excites policy makers and business leaders. They have all now hitting the dirt tracks of the villages to reach the vast untapped market which lies yonder in the rural areas. Here, it should be considered, that the large population will require a wide range of consumable and durable goods and services.

The huge population base in rural India provides a massive opportunity for the companies to sell their products and services on a sizeable scale. Apart from a large population, the increased presence of media and higher literacy level has created a lot of awareness amongst them.

However, it also should be noted that this demand from the large population does not automatically promise a market unless it is backed by adequate purchasing power.

\subsection{Growing Rural Prosperity}

India is now seeing a remarkable swing towards prosperity in rural households.

As per the National Council for Applied Economic Research (NCAER) study, there are as many 'middle income and above' households in the rural areas as there are in the urban areas. There are almost twice as many 'lower middle income' households in rural areas as in the urban areas.

According to NCAER projections, the lowest income class (i.e.Rs. 2500 and below) will shrink by more than $60 \%$, in near future. The higher income classes are likely to double. This actually is the result of development work, which happened under the five years plans and other special programmes such as land reforms, rural electrification rural communication, and rural credit facilities, etc. The absolute size of the rural market is thus expected to double that of urban India.

But despite the high rural share in these categories, the rural penetration rates are low, thus offering tremendous potential for growth. According to Mr. D. Shivakumar, Business, Head (Hair), Personal Products Division, Hindustan Lever Limited, the money available to spend on FMCG (Fast Moving Consumer Goods) products by urban India is Rs. 495,000 million as against is Rs. 635,000 millions in rural India.

\section{Agricultural Growth}

It is the fact that rural India is mostly dependent on agriculture. The agriculture sector in India grew at a rate of only $1.6 \%$ in 2008-09, while the Indian Economy grew at a rate of $6.7 \%$, despite the 2008 Financial Crisis. An extremely slow rate of growth in the agriculture sector of the Indian economy has serious implications for the rural-urban divide, both in terms of income and GDP. Some estimates say that that the average income of a person living in an urban area may be up to 4 times higher than that of a person living in a rural area.

\section{Rising Urbanization}

The rising levels of urbanization in India are a major reason for the rising levels of income disparity in the country. Despite the fact that up to four-fifths of Indian households save money, almost a quarter of them spend more than they earn. As a result there is a shift from agriculture-based jobs to other employment avenues between 2004-05 and 2009-10. While the number of villagers engaged in agriculture fell from 249 million to 229 million, rural construction jobs rose by 88 per cent.

Per capita monthly consumption in rural India grew by 19 per cent during the 2009-10 to 2011-12 period, outpacing growth in spending by urban citizens for the first time since economic reforms began two decades ago on the back of rising wages.

The FMCG producers now realize that there is a lot of opportunity for them to enter into the rural market. The sector is excited about the rural population whose incomes are rising and the lifestyles are changing. There are as many middle income households in the rural areas as there are in the urban. Thus the rural marketing has been growing steadily over the years and is now bigger than the urban market for FMCGs. Globally, the FMCG sector has been successful in selling products to the lower and middle income groups and the same is true in India.

\section{Burgeoning Rural Population}

Over $70 \%$ of sales is made to middle class households today and over $50 \%$ of the middle class is in rural India. The sector is excited about a burgeoning rural population whose 
incomes are rising and which is willing to spend on goods designed to improve lifestyle. Also with a near saturation and cut throat competition in urban India, many producers of FMCGs are determined to formulate bold new strategies for targeting the rural consumers in a big way.

\section{Promotional Effect}

Endorsements of brands are being made by Bollywood celebrities like Amir Khan approving the brand Coca Cola (see picture below) to create a credible impression on the minds of the rural consumers. Actually it has been observed that the rural consumers in general are very guarded in nature while accepting products, and although there is a rise in prosperity and greater acceptance of brands, but their level of awareness regarding brands is still much below the desired level
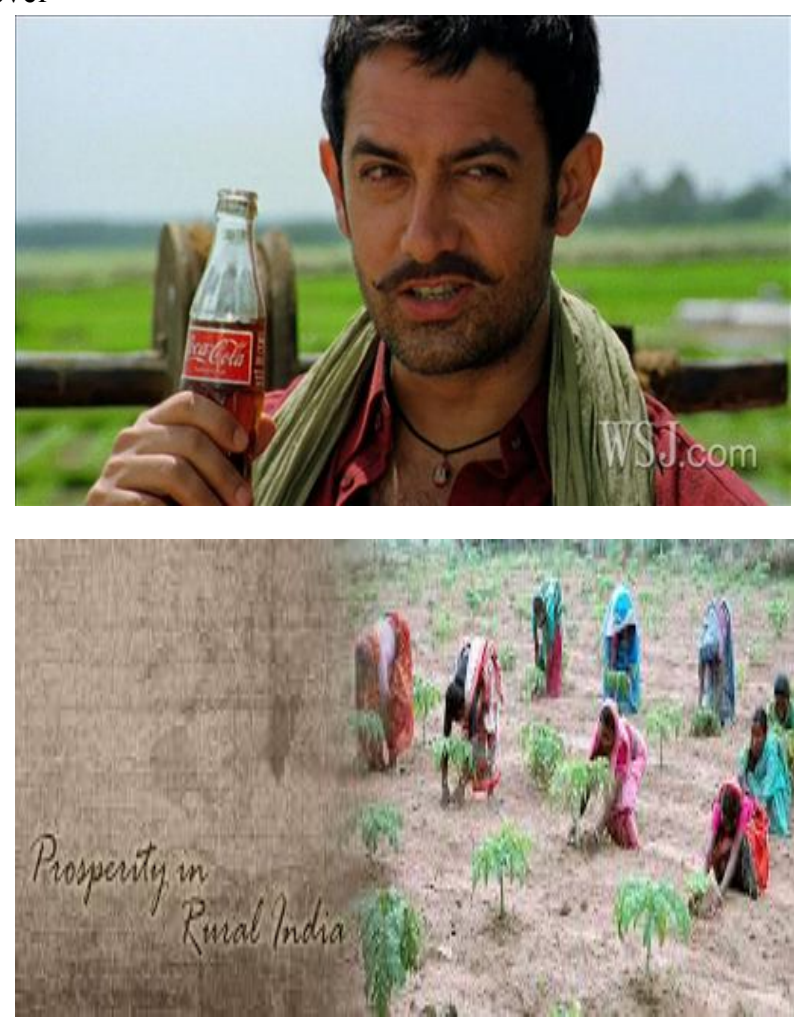

Figure 5. Affluence in Rural India

By 2017, rural markets to surpass urban markets in India; Dr. Dharmendra Singh Gangwar; Joint Secretary, Department of Rural Development, Ministry of Rural Development. According to Dr. Arvind Mayaram,
Additional Secretary \& Financial Advisor, Ministry of Rural Development, Government of India, said that the rate of prosperity growth in rural India is higher than that of urban India.

\section{Rural Market Experiencing a Growth in GDP}

Moreover, Gross Domestic Product (GDP) Growth is increasing at a higher pace in rural areas. About 56 million households in rural areas became prosperous compared to 52 million households in urban. In $2006,70 \%$ of 60 million mobile phone subscribers in India were from rural areas. He also commented that Rs 760,000 million, which is being spent on rural development every year is not capitalizing into long term national asset like, roads, due to lack of maintenance.

Similarly, Dr. Dharmendra Singh Gangwar, said that the rural Indian markets may surpass the urban markets by 2017 . The rural markets have grown from $\$ 220$ billion in 2007 to $\$ 425$ billion in 2010-11 and are expected to continue the growth pace at $12 \%$ CAGR. The schemes like NREGA (National Rural Employment Guarantee Act) have increased the rural purchasing power under which 100 days guaranteed jobs are provided to rural masses enabling them from one meal a day to two meals a day.

The Rural per capita consumption has increased four times faster than earlier due to enhanced economic prosperity in rural areas and BIMARU states (backward economic states viz. Bihar, Rajasthan, Madhya Pradesh \& Uttar Pradesh) have witnessed progress.

"Many states which had been considered backward for a long time, with some of them being called BIMARU (SICK) are now progressing," Singh said in his Independence Day address to the nation, on August 15, 2013.

\subsection{Rising Consumption}

\section{Rise in the Household Income Growth}

The rising consumption in the rural areas is brought about the acceleration in the Household Income Growth in India. The average household disposable income in the rural areas which had grown at $2.8 \%$ per annum between $1985-2000$ is forecasted to grow at a rate of $3.6 \%$ per annum from 2005 to 2025 according to a study made by McKinsey and Company, as depicted in Figure 5. 


\section{HOUSEHOLD INCOME GROWTH WILL ACCELERATE ACROSS INDIA}

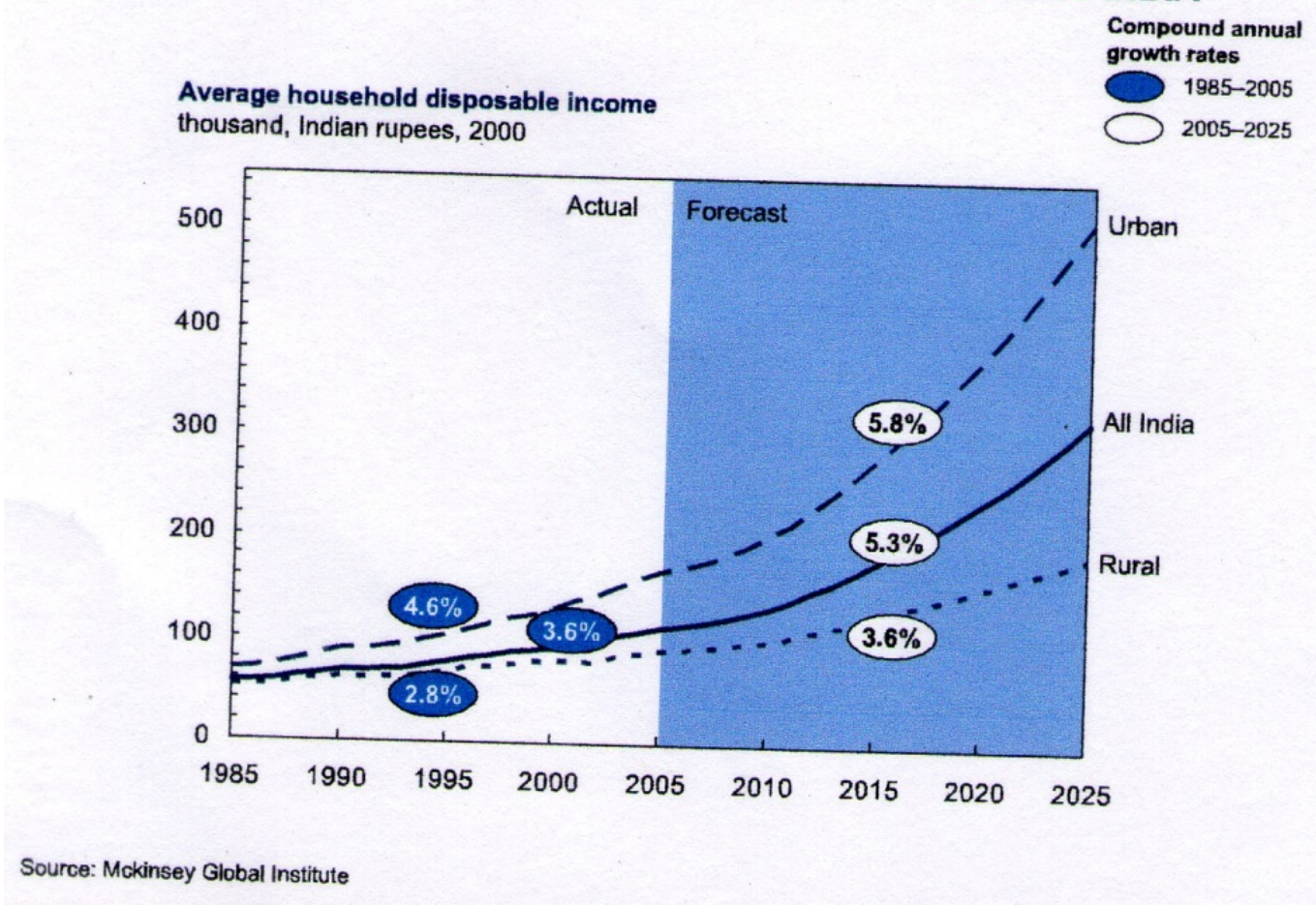

Figure 6. Household Income Growth across India

\section{Substantial Increase in Purchasing Power}

In recent years, rural markets have acquired significance, as the overall growth of the economy has resulted into substantial increase in the purchasing power of the rural communities. On account of the progress that is being experienced in agriculture because of the use of better agricultural inputs, the rural areas are consuming a large quantity of industrial and urban manufactured products.

According to a white paper prepared by CII-Technopak, the rural market grew at an impressive $25 \%$ in the year 2008 and by the year 2010-11 has grown to approximately $720-790$ million customers with a size of US\$425 bn. Rural India has emerged as a large market for numerous goods and services such as financial services.

Rural consumption per person has increased by 19 per cent yearly between 2009 and 2012; two percentage points higher than its urban peers. In incremental terms, spending in rural India during this period, increased by US\$ 69 billion, is significantly higher than US\$ 55 billion by urban populations.

Table 3. Attracting Attributes Of Rural Markets ESTIMATED ANNUAL SIZE : RURAL MARKET

\begin{tabular}{|c|c|}
\hline FMCG & INR 650000 million \\
\hline Durables & INR 50000 million \\
\hline Agri-inputs (including tractors) & INR 450000 million \\
\hline Two / Four Wheelers & INR 80000 million \\
\hline TOTAL & INR $\mathbf{1 2 3 0 0 0 0}$ million \\
\hline
\end{tabular}

Source: (Francis Kanoi, 2002)

\section{Huge Untapped Market}

The immense potential of the rural market can be realized if the marketers understand this market. The huge untapped needs of the rural mass, the growing rural economy and the increasing media penetration and brand awareness make this market extremely attractive to marketers.

A look at the estimated annual size of the rural market (refer Table 3) would make us understand the true potential of this untapped market. The growth statistics for FMCG and Consumer Durables sector suggests huge potential for the Indian Rural markets.

\section{Rural India Consumption is Growing at a Faster Pace than Urban India}

Consumption in rural India is growing at a faster pace than urban India for the first time since economic reforms began two decades ago.

Given the large size of India's rural population, the value of goods and services consumed has always been greater in rural India, but urban India had narrowed the difference during most of the last decade by growing at a faster pace.

The additional spending by rural India between 2009-10 and 2011-12 at Rs.37,50,000 million was significantly higher than Rs.29,94,000 million spent by urbanites, according to ratings agency Crisil.

Growth in rural consumption was fuelled by a rise in household incomes due to greater non-farm job opportunities and government initiated employment generation schemes. NSSO (National Sample Survey Organization) data shows that between 2004-05 and 2009-10 rural construction jobs rose by $88 \%$ while the number of people employed in 
agriculture fell from 249 million to 229 million.

Migrants from villages to urban areas who benefitted from job opportunities in infrastructure and construction projects increased remittances to their families in rural India, which boosted consumption. A notable phenomenon in rural consumption is a shift from necessities to discretionary goods. About one in every two rural households now has a mobile phone.

Even in India's poorest states such as Bihar and Orissa, one in three rural households has a mobile phone. Nearly $42 \%$ of rural households owned a television in 2009-10, up from $26 \%$ five years earlier. Similarly, $14 \%$ of rural households had a two-wheeler in 2009-10, twice that in 2004-05.

"For India, a young population, rising income and low penetration of many consumer durables means that rural consumption has the potential to remain an important source of demand," Crisil said.

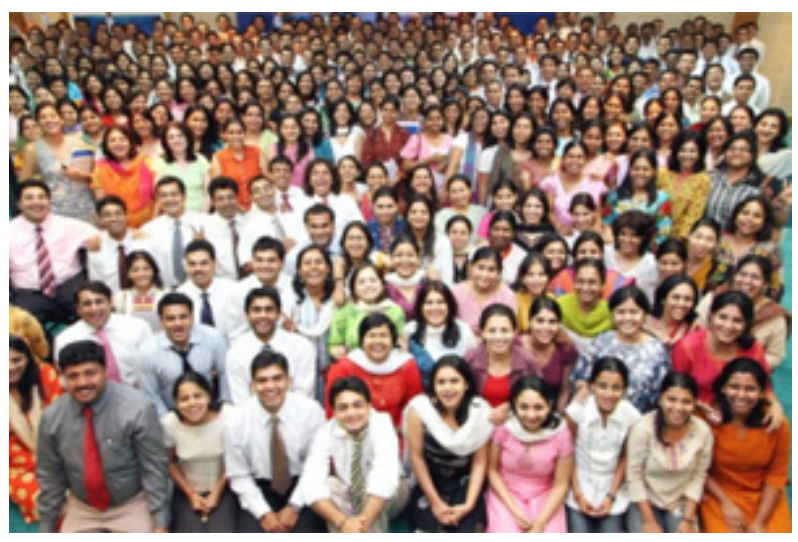

Figure 7. Young Population

The Mahatma Gandhi National Rural Employment Guarantee Scheme (MGNREGS) stimulated job creation on an unprecedented scale and provided an opportunity to rural households to supplement their traditional farm income.

Nearly $27 \%$ of rural households availed employment under MGNREGS in 2009-10. Wages under MGNREGS increase with retail inflation. Consequently, rural wages have risen faster than inflation since 2007-08.

\subsection{Change in Consumption Pattern}

\section{Life Style of Rural Consumer Changed Considerably}

The consumption pattern of rural India has greatly changed. The products which did not find significance in the rural market have slowly gained its place. With the increase in purchasing capacity the rural buyers are not only buying non-durable goods but are also purchasing durable products like TVs, transistors, stereos and two - in - ones. In both non-durable and durable items they are going for branded products. People are wanting entertainment systems, better clothes and education. The secondary needs are increasing fast with passage of time.

Life style of rural consumer changed considerably. There has been increase in demand for durables and non-durables like table fans, radios, mopeds, soaps, etc. by rural consumers. This provides a ready market for the producers. Rural market is expanding day after day.

With changing lifestyles there has been a shift in consumption from carbohydrate staples to protein rich food items. Personal consumption expenditure on food items has seen a decline from $73 \%$ in $1971-72$ to $54 \%$ in 2004 in rural India. Among urban households this expenditure has declined to $42 \%$, thereby underlying the trend that with increase in per capita income, per capita expenditure is spread among other commodities besides food.

The Indian rural consumer is now spending more on consumer durables, apparel, entertainment, vacations and lifestyle related activities. The domestic consumer product markets have become intensely competitive both in the durables and non-durables (FMCG) segment. In a situation where supply is no longer a constraint, consumers are demanding more and better products at much lower prices. Table 4 explains the penetration of consumer durables in 2008

Table 4. Penetration of Consumer Durables

\begin{tabular}{|c|c|c|c|}
\hline & All & Urban & Rural \\
\hline All Households - Mn & 223 & 67 & 156 \\
\hline \multicolumn{4}{|c|}{$\%$ of ownership } \\
\hline Bicycle - Ownership & 52 & 49 & 53 \\
\hline TV - Ownership & 46 & 76 & 34 \\
\hline $\begin{array}{c}\text { Music system ( } 2 \text { in } 1 \text { Walkman, Radio, } \\
\text { CD etc.) Ownership }\end{array}$ & 22 & 29 & 19 \\
\hline Refrigerator - Ownership & 13 & 32 & 5 \\
\hline $\begin{array}{l}\text { Telephone (Landline/ } \\
\text { Terrestrial)/Wireless line - } \\
\text { Ownership }\end{array}$ & 12 & 21 & 7 \\
\hline Motorcycles - Ownership & 10 & 18 & 7 \\
\hline Air cooler - Ownership & 7 & 17 & 3 \\
\hline DVD Player - Ownership & 6 & 15 & 2 \\
\hline Washing Machines - Ownership & 4 & 13 & 1 \\
\hline Still camera - Ownership & 3 & 9 & 1 \\
\hline Scooters - Ownership & 3 & 8 & 1 \\
\hline Mopeds - Ownership & 2 & 5 & 1 \\
\hline Computer at Home - Ownership & 2 & 5 & 0.3 \\
\hline Car - Van - Jeep Ownership & 2 & 2 & 1 \\
\hline Air conditioner - Ownership & 1 & 3 & 0 \\
\hline Digital Camera - Ownership & 1 & 2 & 0.1 \\
\hline Microwave Oven - Ownership & 1 & 2 & 0 \\
\hline Vacuum cleaner - Ownership & 0.5 & 2 & 0.0 \\
\hline Cooking Range - Ownership & 0.3 & 1 & 0.0 \\
\hline Video Camera/ Cam Order - Ownership & 0.2 & 0.5 & 0.03 \\
\hline
\end{tabular}

Source: Indian Readership Survey 2008

A convergence is observed in the consumption pattern of urban and rural households from the following graph. 


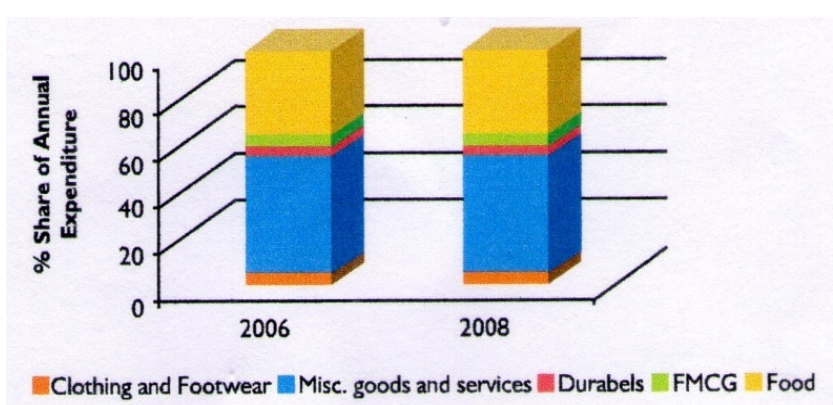

Source: Calculated from Market Skyline of India 2008-09.

Figure 8. Consumption Pattern of Indian Households

Thus the major shift in the consumption pattern can be summarized as:

- People, both in rural and urban areas are spending proportionately less on food items and more on transportation, running their own vehicles as well as making use of transport services People are travelling and also incurring higher costs due to fuel price inflation, and looking for better quality transport

- More expenditure on health is being incurred and for general well-being. The cost of medical care has gone up, while there has been an increase in life expectancy, which means that people are living longer with better medical care

- People are spending more on fuel and power at our homes. The cost of energy has gone up and will continue to grow with greater consumption of electrical goods

However, apart from low penetration, even the per capita consumption in most of the FMCG categories in India is low as compared to both the developed markets and the emerging economies. Although the poverty in India has reduced, significantly, there are still about 110 million households who live on less than Rs.75,000/- per annum. The good news is that this segment is shrinking dramatically in urban India and a slightly lower pace in rural India.

\subsection{Rural Market Growing More than the Urban Market}

The rural economy, in the past 20 years, has transitioned into a thriving economy. Rapid increase in rural literacy levels, improvement in health indicators, and increase in per capita expenditure, improvement in housing, decline in poverty levels and increase in life expectancy are factors that have resulted in the improvement of human development indicators in rural India.

\section{The Evolution in the Rural Economy}

The change has taken place in the rural economy on three levels viz. Food grain crops, on land activities and farm activities.
The resultant shift is owing to the high opportunity of value addition, bringing about high rural incomes. The farm sector now contributes 40 per cent of the rural income while the non-farm sector adds 60 per cent to the rural income. This changeover has important positive implications for employment and productivity, both with the farm and non-farm sectors which have grown considerably.

India's rural markets present opportunities that companies seeking to become high-performance businesses cannot afford to ignore. But the size and scale of those markets (three-fourths of the country's approximately 1.1 billion people live in villages) have been offset by concerns about the profitability of these markets and the durability of rural demand. Now, though, there is abundant evidence to indicate that businesses are seeing more promise in India's hinterland. There are several strong regional and macroeconomic reasons for greater confidence. And, there is a growing body of statistics to demonstrate that rural markets, fueled in part by rising purchasing power, hold real prospects for profitable growth across a wide range of industry sectors.

Five reasons for greater business confidence in rural India are as follows:

a) Rural spending is now less dependent on farm income, which now constitutes less than 50 percent of the total rural income. Income remittances from migrant rural populations and increases in nonfarm activities such as trading and agro-processing are boosting on farm income.

b) The increase in procurement prices (the minimum price that farmers earn on produce sold to the government) is putting more money into the hands of the rural population. A series of good harvests, on the back of several good monsoons from 2005 to 2008, has accelerated rural employment in agricultural and allied activities.

c) The government has increased spending in rural areas, from US\$9 billion for the financial year ending March 2007 to an anticipated US\$16 billion for the financial year ending March 2010 (refer Figure 5)

d) Improved access to finance and institutional credit has brought greater cash inflows to rural households. Institutional credit to the agriculture and allied sectors increased from INR695.6 billion (US\$14.5 billion) in 2002-03 to INR2.6 trillion (US\$55 billion) in 2008-09.

e) Policy measures such as the US\$13.9-billion waiver of agricultural loans and the National Rural Employment Guarantee Scheme (NREGS), which guarantees 100 days of employment to one member of every rural household, have helped to reduce rural under-employment and raised wages. The official minimum average per-day wage paid under NREGS has increased from INR65 (US\$1.4) in 2006-07 to INR84 (US\$1.8) in 2008-09. 


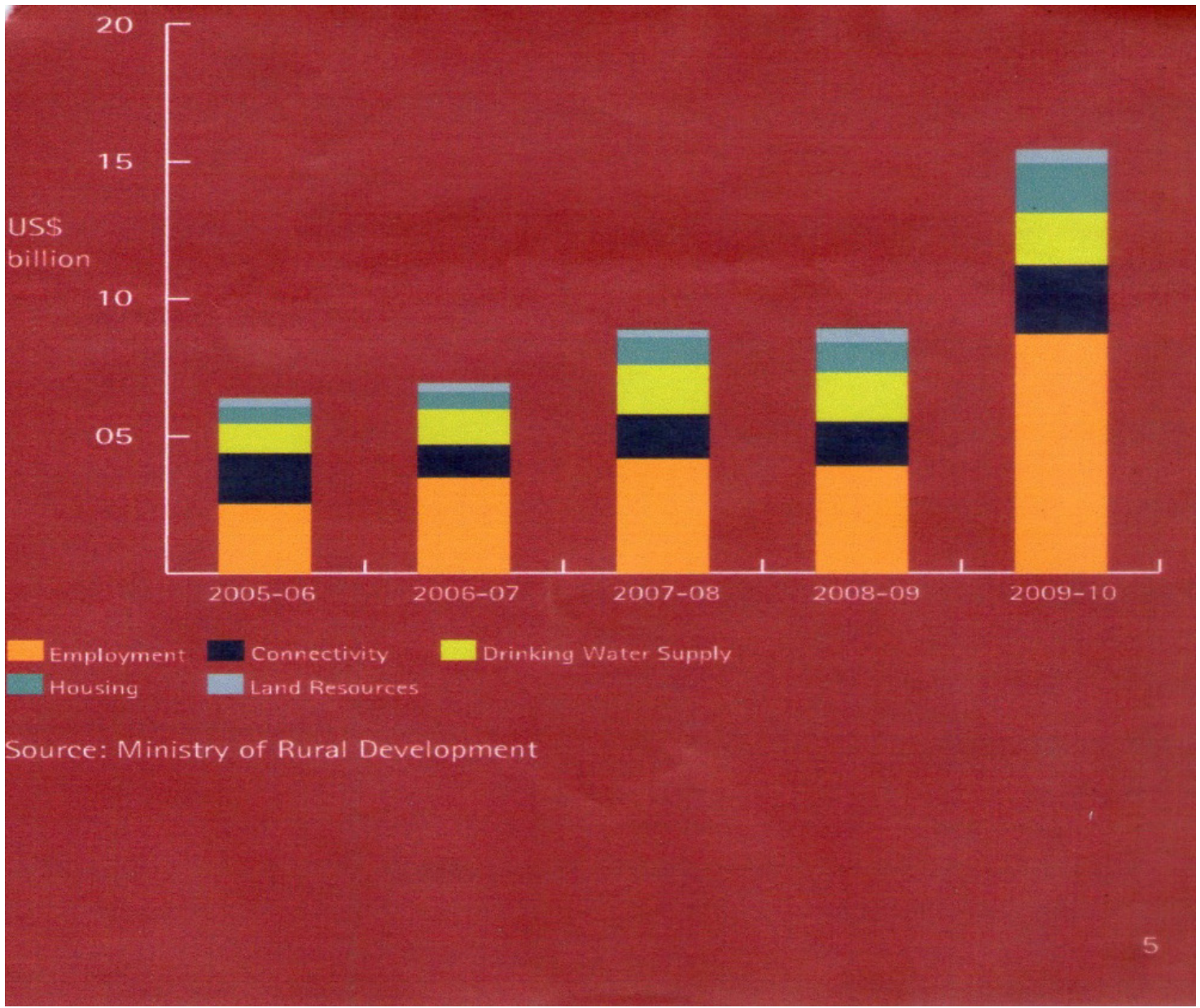

Source : Ministry of Rural Development

Figure 9. Government Budgeted Expenditure

\section{Rural India Spending More than Urban Areas}

People in rural India are spending more than those in urban areas, according to a study by Accenture, a multinational management consulting, technology services and oil company.

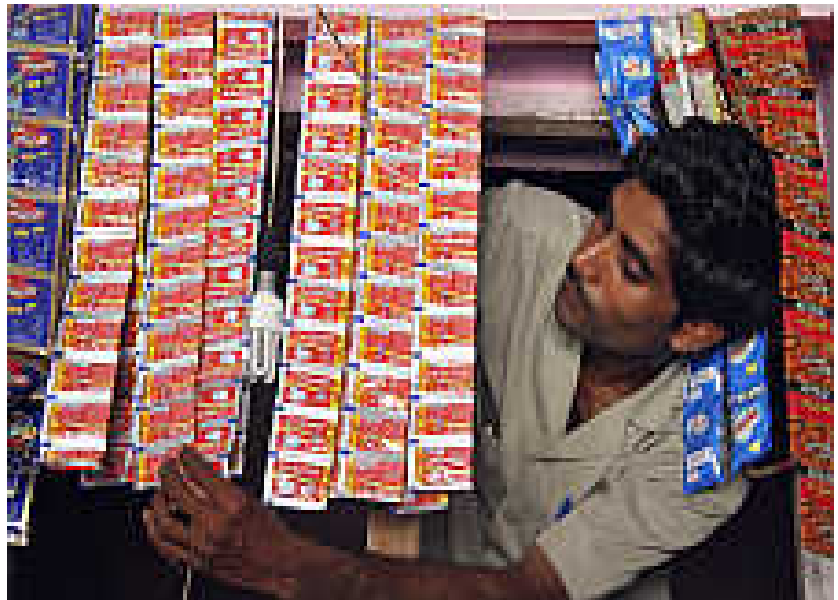

Figure 10. Shop in a Village

Rural markets are becoming attractive for a number of reasons. Since 2000, per capita Gross Domestic Product has grown faster in India's rural areas than in its urban centres: 6.2 per cent CAGR (compounded annual growth rate) versus 4.7 per cent. Rural incomes are growing, and consumers are buying discretionary goods and lifestyle products, including mobile phones, television sets and two-wheelers.

Between 2009 and 2012, spending in rural India reached $\$ 69$ billion, significantly higher than the $\$ 55$ billion spent by the urban population. The rush to rural markets is not a recent phenomenon and companies have been testing these markets for some time.

\section{Innovative Techniques to Reach the Rural Consumers}

Successful companies, whom we refer to as Rural Masters, have used innovative techniques to reach the rural consumers and scale operations profitably.

All this while, Rural Masters have worked very closely with the rural diasporas and have spent a number of years to understanding the rural consumer's attitudes and behaviours. They have been tweaking their operating model; in some cases using a combination of different channel strategies to effectively reach the rural consumer.

Rural Masters demonstrate consistent streaks of innovation in how they reach, acquire and retain the rural consumers, which has helped them capture the minds and 
wallets of the rural consumers.

The expansion to rural is not restricted to a particular sector. Companies from FMCG, healthcare, banking and finance and auto and telecom have expanded their operations to rural areas.

\subsection{Urban Market Reaching a Saturation State}

\section{A Significant Transmutation Indian Marketing}

Indian marketing is undergoing a significant transmutation because of economic liberalization and globalization. Both national and global players are trying to capture the urban markets of India, which has already reached a saturation level, and it is extremely difficult to tap the urban markets with high profit margin. The urban market is getting saturated and thus is enable to provide the much needed market to many companies and in search of greener pastures many of these companies are now targeting the rural market.

The reasons for the change around is because of the fact that in the past four years or so, disposable incomes in Indian villages have risen as a result of the nearly- $80 \%$ increase in minimum support price of crops as well as the increase in employment.

A plethora of infrastructure projects across the length and breadth of the country have created employment opportunities, even in rural India and, also the National Rural Employment Guarantee Act has come as a boon. Also the improvement in infrastructure has made it easier for companies to reach these customers.

Urban markets are fast reaching saturation at all levels. Be it cellphone connections, washing machines, television sets or bank accounts, you name it and everyone in urban India has at least one. The replacement market is also not growing at the expected levels of the companies.

\section{Rise in Rural Aspirations}

In the rural market it is observed that the rural customers are not only eager to buy goods but that they have an increasing purchasing capacity. Rural India has much more money to spend. So it is no more the concept of brand push by the corporate that finds ground - it is the customer pull that becomes more significant.
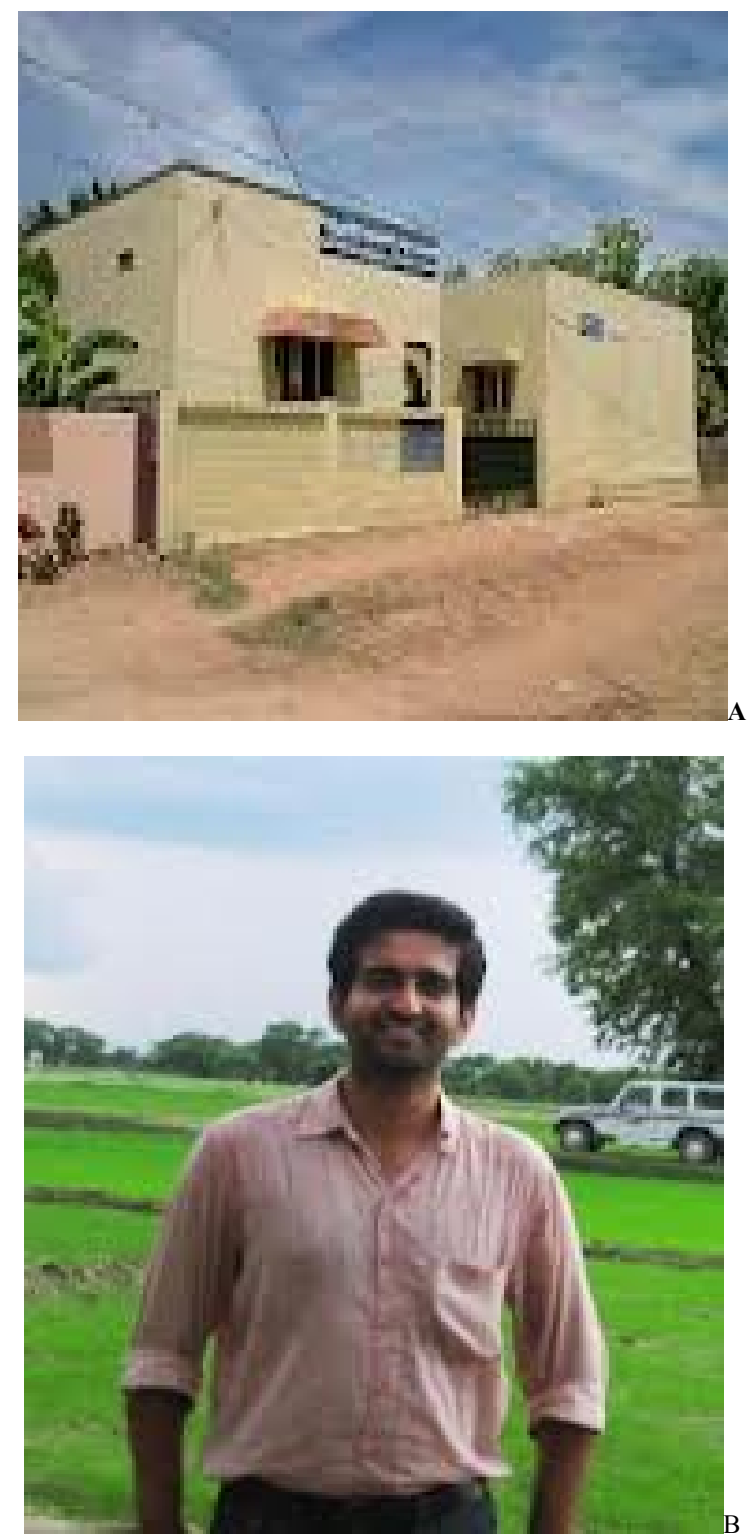
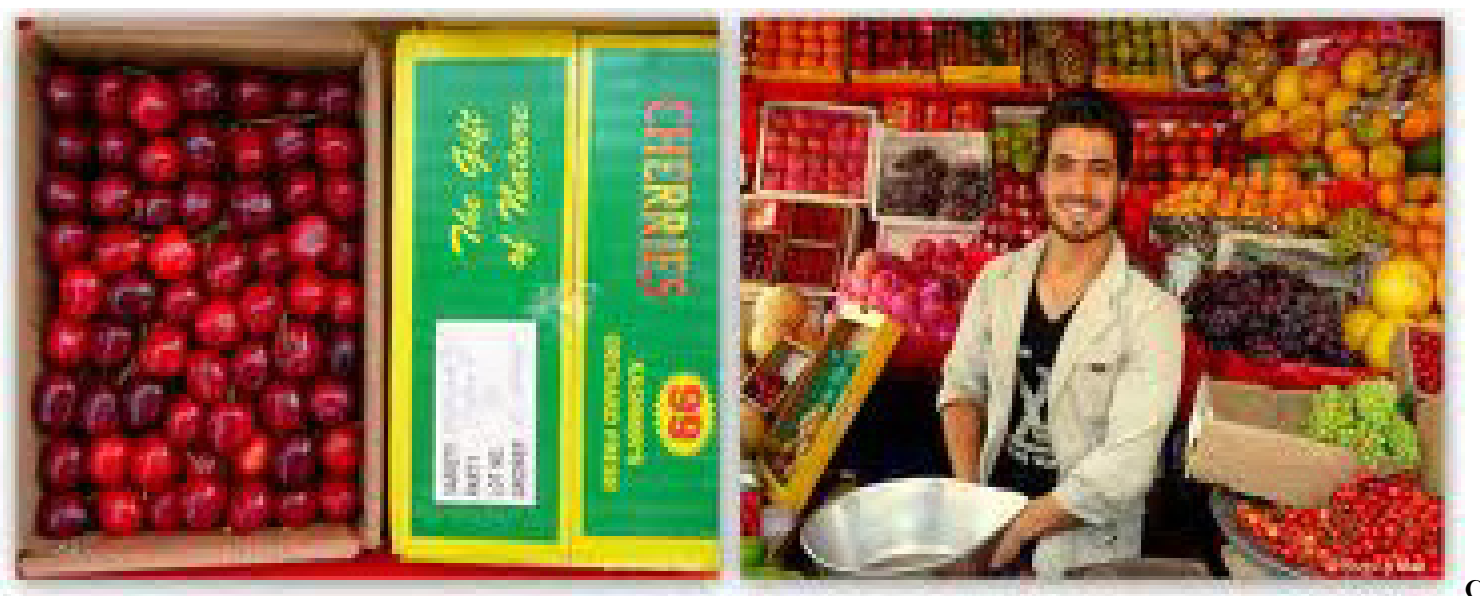

Figure 11. Rural Aspirations 
The villages have money and their aspirations are growing as fast as - if not faster than - their incomes. Together, they form a market that's expected to grow even faster than urban India in many sectors. According to a study by Mart, rural India buys $46 \%$ of all soft drinks sold in the country, $49 \%$ of motorcycles and $59 \%$ of cigarettes, while $11 \%$ of rural women use lipstick. This is a very big opportunity for the companies to exploit.

\subsection{Decision Making Units in Rural India and What are Their Involvements in the Basket of Choices}

\section{Role of Decision Making Units}

The decision making in rural India is generally male driven. Be it FMCG or consumer durables decisions of purchasing or brand selection is made by the male folk. However, owing to low level of literacy and also since there is also low level of brand awareness, rural people opt for collective bargaining. They form into formal and informal groups with the close knit relationships they have amongst the people in their villages.

These are known as Reference Groups which may be:

- Informational : Giving information about products used by others in the village

- Normative : The need to belong to a group

A consumer is also influenced by emerging social factors in the environment lives and works in They constitute the traditional reference groups, the role played by family, friends and opinion leaders

The Opinion Leaders play a great role in rural decision making. He or she is person whose words and actions informally influence the action or attitude of others. The influence is informal and is usually verbal. In some cases however, the influence could be non-verbal, this would be from an opinion leader who is a leader of social status, power or success in public life.

The traditional opinion leaders have been the gram pradhan or sarpanch. He has always been considered as a leader by his caliber of interacting with the media, government leaders. He solves different problems in the village ranging from social and family conflicts, usage of new methods of farming, to the purchase of technology products for farming or artisan work.

Since independence, with spread of education, teachers in the villages have been considered as emissaries of knowledge. But it is observed that with more village children taking higher education, the influence of school teacher is restricted amongst school students.

The rural youth is also becoming opinion leaders in the social circles. They influence the purchase of new products. They have become reference points and influencers for recommendations of varieties of consumer durables viz. TV, refrigerator, motorcycle etc.

The rural youth who starts earning in the family becomes the influencer in the family decision making process. He influences the ideas of the family and takes part in improving the economic position of the family and inculcating higher values in the society.

The family and friends also constitute the reference points in rural India. People meet socially with families or visit each other houses quite often to interact and exchange views and ideas.

Male members meet at village community meetings and women also talk with other women while performing their work.

A rural neighbor is a person to reckon with. They form a part of the extended family in the village circles. All new purchases are discussed and vetted after discussion with the neighbors.

Children are becoming important decision makers in rural decision making. With the spread of education, the children in rural India are taking part in deciding and advising their elders as to the brand of TV to buy, brand of refrigerator to choose, which paint to colour the house and rooms etc.

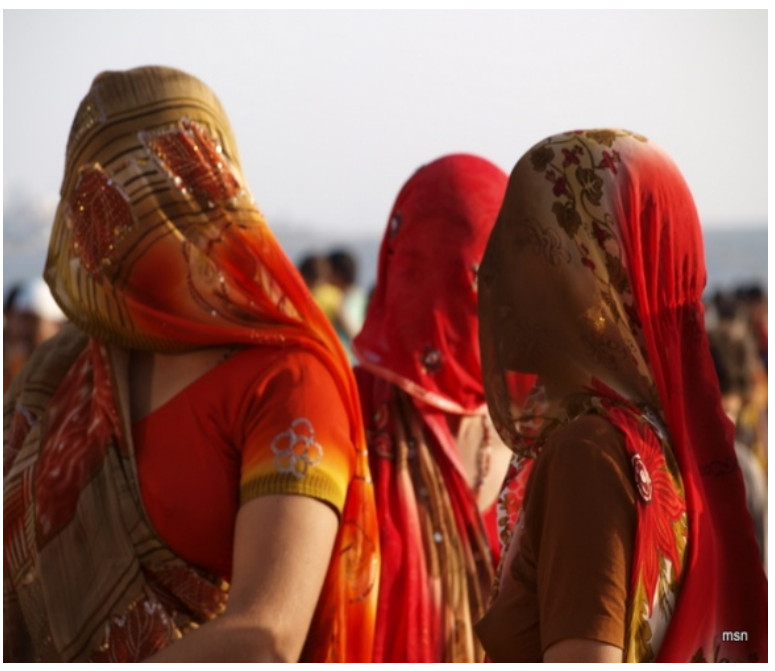

A. Yester years

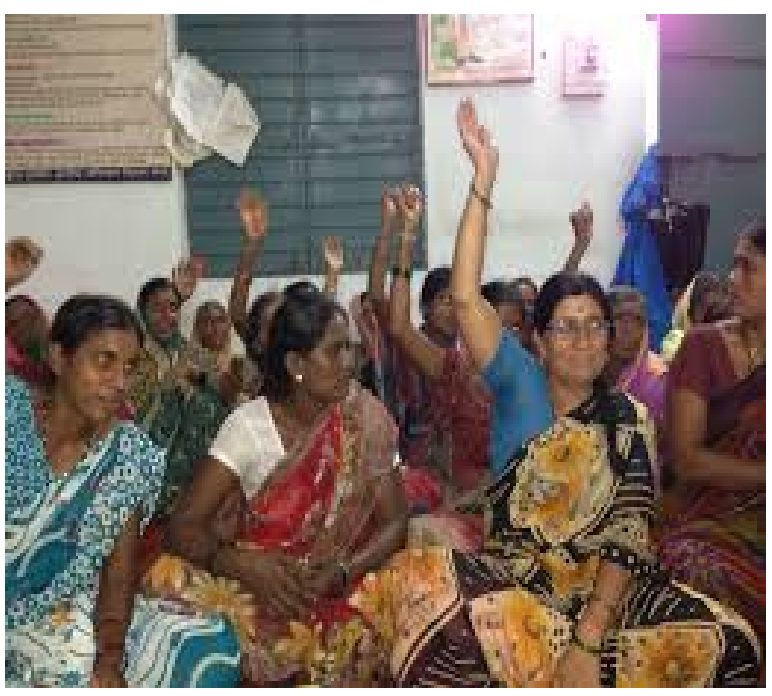

B. Presently

Figure 12. Role of women in decision making 


\section{Role of Village Women}

Women, till few years back, were considered only for performing household duties. They were meant for cooking food for the family members, rearing children in the family. They hardly left their homes and that too on social occasions only. They were to follow the purdah system, which was a custom of the day. But today, their status is changing. They are more educated and are more aware of health and education requirements in the family. The increasing influence of the media has had a strong authority on their role and behavior. Several organizations like Hindustan Unilever Limited, ITC have come forward to empower these rural women by monetary benefits and making them financially self-sufficient.

\section{Conclusions}

Thus, looking at the scope of rural marketing, which rural markets offer to the marketers, it can be said that the future is very promising for those who can understand the dynamics of rural markets and exploit them to their best advantage. A radical change in attitudes of marketers towards the vibrant and burgeoning rural markets is called for, so they can successfully impress on the 833 million rural consumers spread over approximately six hundred thousand villages in rural India.

The future of India lies in its rural markets. It needs to be nurtured properly and professionally so that it could bear optimistic results to the marketers who would explore its treasures with gratifying expectations

\section{REFERENCES}

[1] Census 2011 - Provisional Population Totals - India

[2] ET Bureau Aug 29, 2012

[3] Per capita consumption rising faster in rural areas : ARVIND JAYARAMBL RESEARCH BUREAU

[4] Social Changes and the Growth of Indian Rural Market : An Invitation To FMCG Sector S John Mano Raj*,Dr. P Selvaraj

[5] IBN Live : PTI : posted on August 15, 2013

[6] (Rural Indians outpace urbanites in spending growth: Report M Allirajan, Aug 29, 2012, Times of India)

[7] Changing Pattern of the Indian Market : Strategic Issues : Ravi Shanker \& Debdeep De

[8] From India to Bharat : by Rashmi K. Pratap, Tanisha Kulshrestha, Outlook Business ,July 9,2011

[9] Participation of Rural Women in Decision Making, A. Mishra, A. Mishra, and A.K. Dubey, Indian Res. J. Ext. Edu. 9 (3), September, 2009

[10] Rural Marketing by Pradeep Kashyap, second edition, Pearson 